\title{
PENGEMBANGAN PERANGKAT PEMBELAJARAN BIOLOGI BERBASIS METAKOGNITIF UNTUK MELATIHKAN KEJUJURAN SISWA
}

\author{
Mochammad Yasir'), Muslimin Ibrahim²), Wahono Widodo ${ }^{3)}$ \\ ${ }^{1)}$ Mahasiswa Program Studi Pendidikan Sains, Program Pascasarjana Universitas Negeri Surabaya \\ ${ }^{2), 3)}$ Dosen Pascasarjana Prodi Pendidikan Sains Univesrtitas Negeri Surabaya \\ E-mail: idlmy.354@gmail.com
}

\begin{abstract}
The purpose of this research is produce Biology learning material based on metacognitive that valid, practical, and effective to practice reflective thinking skill. The development of learning material use the 4-D model and try out to do in class $\mathrm{X}$ 1 and X-2 of SMAN 1 Driyorejo second semester in academic year 2014/2015. Design of try out is One-Group Pretest-Posttest Design. The method of collecting data used document, observation, validation, test, and quetionnaires. The data analysis techniques used descriptive analysis of quantitative and qualitative. The results of this research are: 1) learning material developed has a valid category; 2) learning material in terms implementation of lesson plans category in feasibility and the activities of students according to the steps of metacognitive learning strategies with STAD cooperative model; and 3) the effectiveness of learning material in terms of: (a) improving student aspect of knowledge learning outcomes visible from the ngain score with high category; (b) the completeness honesty of students respectively by $82.64 \%$ and $86.11 \%$ with the good category; c) the students responds toward material and implementation of learning positive. The conclusion is acquired from the results of this research show that the learning material based on metacognitive are proper valid, practical, and effective to practice reflective thinking skills of student.
\end{abstract}

Keywords: Learning material, metacognitive, and honesty

Abstrak: Tujuan penelitian ini untuk menghasilkan perangkat pembelajaran Biologi berbasis metakognitif yang valid, praktis, dan efektif untuk melatihkan kejujuran siswa. Pengembangan perangkat pembelajaran menggunakan model 4-D dan uji coba dilakukan di kelas X-1 dan X-2 SMAN 1 Driyorejo semester genap tahun ajaran 2014/2015 dengan rancangan penelitian OneGroup Pretest-Posttest Design. Pengumpulan data menggunakan metode dokumen, observasi, validasi, tes, dan angket. Teknik analisis data menggunakan analisis deskriptif kuantitatif dan kualitatif. Hasil penelitian menunjukkan: 1) perangkat pembelajaran yang dikembangkan berkategori valid; 2) perangkat pembelajaran ditinjau dari keterlaksanaan RPP berkategori praktis dan aktivitas siswa sesuai pada tahap-tahap strategi belajar metakognitif dengan model kooperatif tipe STAD; dan 3) keefektifan perangkat pembelajaran ditinjau dari: (a) peningkatan hasil belajar aspek pengetahuan siswa terlihat dari n-gain dengan kategori tinggi; (b) ketuntasan kejujuran siswa masing-masing sebesar $82,64 \%$ dan $86,11 \%$ dengan kategori baik; dan (e) respon siswa terhadap perangkat dan pelaksanaan pembelajaran positif. Simpulan yang diperoleh dari hasil penelitian menunjukkan bahwa perangkat pembelajaran berbasis metakognitif yang dikembangkan layak valid, praktis, dan efektif untuk melatihkan kejujuran siswa.

Kata kunci: Perangkat pembelajaran, metakognitif, dan kejujuran

\section{PENDAHULUAN}

Biologi merupakan cabang ilmu Sains yang mengkaji pengetahuan tentang makhluk hidup dan alam sekitar, serta menekankan bukan hanya penguasaan kumpulan pengetahuan berupa fakta-fakta, konsep-konsep atau prinsip-prinsip saja, tetapi juga merupakan suatu proses penemuan yang diperoleh melalui metode ilmiah. Ekosistem merupakan salah satu materi biologi. Materi ini secara umum sudah disampaikan sejak SMA, namun pembelajaran yang dilakukan masih bersifat hafalan dan kurang mengembangkan kemampuan berpikir melalui pemecahan masalah dengan berpegang pada sikap- sikap ilmiah, salah satunya jujur (Rustaman, 1997). Jujur adalah perilaku yang didasarkan pada upaya menjadikan dirinya sebagai orang yang selalu dapat dipercaya dalam perkataan, tindakan, dan pekerjaan. Kejujuran akan tercermin dalam perilaku yang diikuti dengan hati yang lurus (ikhlas), berbicara sesuai dengan kenyataan, berbuat sesuai bukti dan kebenaran. Kejujuran merupakan salah satu unsur kekuatan spiritual, akhlak mulia, serta kepribadian (Emosda, 2013).

Tujuan utama sebuah pendidikan adalah membentuk kejujuran, sebab kejujuran adalah modal dasar dalam kehidupan bersama dan kunci menuju 
keberhasilan. Kejujuran dapat mengindikasikan bagaimana siswa mengatur proses kognitifnya melalui pemberdayaan keterampilan metakognitif (Case, 2000; Nindiasari, 2011).

Berdasarkan hasil observasi yang dilakukan peneliti (2013) siswa yang tidak belajar sebelum tes atau belajar ketika akan ada tes saja, akan merasa tidak siap untuk memberikan jawaban yang benar. Hasil observasi pembelajaran (November-Desember 2014) memperkuat pernyataan tersebut. Ketidakjujuran siswa dapat dilihat pada saat mengumpulkan makalah, siswa menyalin karya orang lain tanpa menyebutkan sumber, pada saat tes masih banyak siswa yang menyontek teman sebangku, ataupun melihat jawaban pada buku yang dimiliki, dan kurang bisa mengakui kesalahan maupun kekurangan yang dimiliki. Hal tersebut menjadi indikator kejujuran siswa masih rendah. Oleh karena itu, jujur sangat penting untuk ditanamkan dan dilatihkan secara terus menerus mulai sejak usia dini sesuai Kurikulum 2013 (Kemendikbud, 2013).

Pendekatan yang dapat melatihkan kejujuran siswa, di antaranya adalah pendekatan metakognitif. Hal ini dikarenakan pembelajaran dengan pendekatan metakognitif siswa dapat menumbuhkan sikap jujur (Susantini, 2009a). Jadi, pembelajaran materi ekosistem sangat memungkinkan untuk dikembangkan dengan strategi belajar metakognitif untuk melatihkan kejujuran siswa. Pembelajaran metakognitif bermanfaat bagi siswa karena metakognitif dapat meningkatkan hasil belajar secara nyata dan mengembangkan karakter jujur, berani mengakui kesalahan, dan dapat menilai diri sendiri (Susantini, 2009b). Siswa yang menggunakan keterampilan metakognitif memiliki prestasi lebih baik dibandingkan siswa yang tidak menggunakan keterampilan metakognitifnya. Hal ini akan tercapai, apabila siswa mampu berpikir tentang proses berpikir yang dimilikinya, mengidentifikasi strategi belajar yang baik dan secara sadar mengarahkan belajarnya (Ho dan Kelly, 2010).

Berdasarkan latar belakang masalah yang terjadi, peneliti bermaksud untuk mengembangkan perangkat pembelajaran yang diharapkan dapat melatihkan kejujuran siswa.

\section{METODE PENELITIAN}

Perangkat pembelajaran yang dikembangkan meliputi: 1) Rencana Pelaksanaan Pembelajaran (RPP); 2) Lembar Penilaian Pemahaman Diri (LPPD); 3) Buku Ajar Siswa (BAS); 4) Instrumen penilaian hasil belajar. Proses pengembangan perangkat pembelajaran mengacu pada model pengembangan 4-D (Thiagarajan dan Semmel, 1974). Tahap pendefinisian dan perancangan dilakukan pada bulan SeptemberFebruari di Pendidikan Sains, Pascasarjana Unesa.
Tahap pengembangan melalui uji coba dilakukan di kelas X-1 dan X-2 SMA Negeri 1 Driyorejo Gresik, semester genap tahun ajaran 2014/2015. Subjek penelitian sebanyak 72 siswa kelas X-I dan X-2 SMA Negeri 1 Driyorejo Gresik. Variabel-variabel yang berkaitan dengan penelitian ini adalah 1) perangkat pembelajaran berbasis metakognitif; 2) validitas perangkat pembelajaran; 3) kepraktisan perangkat pembelajaran, meliputi: a) keterlaksanaan RPP, dan b) aktivitas siswa; serta. 4) keefektifan perangkat pembelajaran, meliputi: a) peningkatan hasil belajar, b) tingkat kejujuran siswa, dan c) respon siswa. Instrumen penelitian yang digunakan adalah lembar validasi, lembar pengamatan keterlaksanaan RPP, lembar pengamatan aktivitas siswa, tes, lembar pengamatan sikap, dan angket respon siswa. Metode pengumpulan data menggunakan metode dokumentasi, observasi, validasi, tes, dan angket, yang kemudian dianalisis secara deskriptif kuantitatif dan kualitatif.

\section{HASIL PENELITIAN DAN DISKUSI}

Hasil validasi perangkat pembelajaran yang dikembangkan, meliputi: 1) Rencana Pelaksanaan Pembelajaran (RPP) mendapat skor 3,61 (kategori sangat valid); 2) Lembar Penilaian Pemahaman Diri (LPPD) mendapat skor 3,64 (kategori sangat valid); 3) Buku Ajar Siswa (BAS) mendapat skor 3,54 (kategori sangat valid); 4) Instrumen penilaian hasil belajar, yaitu instrumen tes pengetahuan mendapat skor 3,9 (kategori sangat valid) dan lembar pengamatan sikap siswa mendapat skor 3,94 (kategori sangat valid). Hasil tersebut menunjukkan RPP, LPPD, BAS, dan instrumen penilaian hasil belajar yang dikembangkan sangat valid untuk dijadikan panduan bagi siswa maupun guru dalam proses pembelajaran setelah direvisi sesuai saran dari validator. Kevalidan perangkat pembelajaran dalam pengembangannya didasarkan beberapa analisis, meliputi: 1) analisis kurikulum, yang mengacu pada: a) kompetensi inti, b) kompetensi dasar, c) indikator, dan d) rumusan tujuan pembelajaran sehingga disesuaikan dengan isi kurikulum 2013;2) analisis siswa dengan menelaah tentang karakteristik siswa (meliputi umur, tingkat kedewasaan, kemampuan, latar belakang pengetahuan, dan tingkat perkembangan kognitif siswa, serta kejujuran dan atensi siswa), yang sesuai dengan rancangan dan pengembangan bahan pelajaran; 3) analisis tugas dan konsep materi, yang didasarkan pada tugas-tugas yang perlu dilakukan siswa dalam materi pelajaran yang harus dimengerti siswa dan identifikasi terhadap konsep-konsep utama yang diajarkan dan menyusunnya secara sistematis dalam bentuk peta konsep; 4) analisis tujuan yang ingin dicapai dengan mengacu pada: a) strategi metakognitif sebagai pertimbangan dalam menyusun RPP, LPPD, BAS, instrumen hasil belajar sehingga 
perangkat pembelajaran tersebut mencerminkan ciri metakognitif.

Keterlaksanaan perangkat pembelajaran diamati dua orang pengamat. Pengamatan dilakukan selama 3 kali pertemuan, yang merupakan implementasi dari RPP 1, RPP 2, dan RPP 3. Sintaks pembelajaran mengikuti model pembelajaran kooperatif tipe STAD dengan strategi metakognitif. Pada RPP terdapat tiga kegiatan yaitu pendahuluan, kegiatan inti, dan kegiatan penutup. Pada tiga bagian utama tersebut sudah termaktub sintaks dari metakognitif yang telah dikembangkan. Secara keseluruhan semua tahap-tahap kegiatan yang ada di dalam RPP pada uji coba replikasi di dua kelas, yaitu kelas X-1 dan kelas X-2 terlaksana dan persentase keseluruhan keterlaksanaan RPP dari 2 kelas tersebut adalah 91,25\% dengan kategori sangat baik (Ratumanan \& Laurens, 2011) (Gambar 1). Instrumen keterlaksanaan RPP mempunyai rata-rata reliabilitas $93,56 \%$ dan berkategori sangat baik (Borich, 1994).

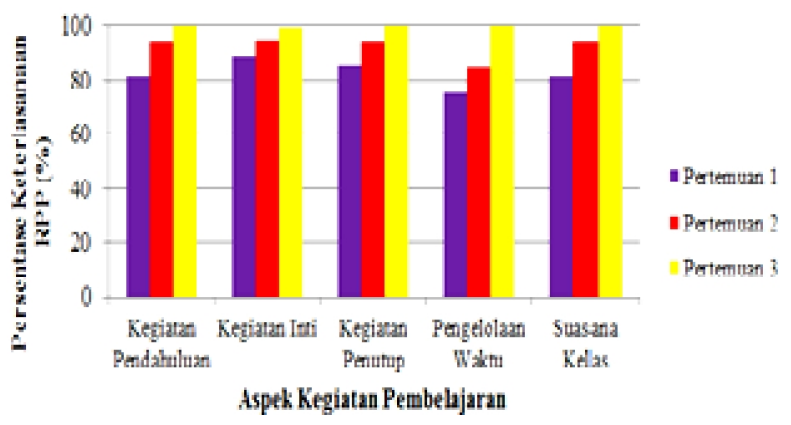

Gambar 1. Keterlaksanaan RPP pada uji coba II di kelas X-1 dan X-2 secara keseluruhan

Skor rata-rata yang tinggi dan dengan kategori sangat baik tersebut dikarenakan semua tahap pembelajaran terlaksana dan beberapa hal lain yang mendukung yaitu: Pertama, pada kegiatan pendahuluan; sebelum memulai pembelajaran guru memulai PBM dengan berdoa untuk menanamkan kesadaran dan rasa syukur sebagai wujud rasa ekspresi kekaguman atas kebesaran Tuhan, menarik perhatian siswa dengan focuser (Class-Yess, Are You Ready), memotivasi siswa dengan mengajukan masalah autentik ekosistem, menjelaskan tujuan PBM. Hasil tersebut mengindikasikan bahwa guru berhasil dalam membimbing siswa untuk menyiapkan siswa dalam kegiatan pembelajaran, memfokuskan perhatian, dan siswa aktif berpartisipasi dalam pembelajaran.

Motivasi mendorong dan menggiatkan siswa untuk meniru model dan menarik perhatian siswa agar siswa merasa penting untuk mempelajarinya (Barakatu, 2007). Hal tersebut sesuai dengan teori belajar penemuan oleh Bruner menyarankan agar siswa hendaknya belajar melalui partisipasi secara aktif dalam memperoleh pengalaman belajar (Slavin, 2009).
Kedua, pada kegiatan inti, guru mendapatkan skor dengan kategori sangat baik. Ini dikarenakan fase-fase pembelajaran berbasis metakognitif dilaksanakan guru, seperti pemberian motivasi dan penyampaian indikator, secara mandiri siswa mengerjakan LPPD, yang berfungsi untuk menentukan tingkat keyakinan diri, bersama kelompok kerja siswa mengerjakan LPPD, yang berfungsi untuk membandingkan konsep awal dengan konsep yang baru diperoleh dari hasil diskusi dengan bantuan buku siswa, mempresentasikan hasil diskusi kelompok dalam diskusi kelas, membuat simpulan, dan penilaian diri.

Ketiga, pada kegiatan penutup yaitu fase Keempat guru membimbing merangkum materi pembelajaran. Siswa mengajukan pendapat tentang konsep yang diperolehnya dan guru memfasilitasi serta memediasi agar siswa membentuk jejaring pengetahuan sesuai tujuan pembelajaran. Cara seperti ini dapat membantu siswa memasukkan konsep yang baru diperoleh ke dalam memori jangka panjang. Nur (2005) menyatakan bahwa cara untuk menyimpan di dalam memori jangka panjang ini adalah dengan pengulangan atau pengkodean.

Keempat, pengelolahan waktu terlaksana dengan kategori baik. Hal tersebut mengindikasikan terjadi peningkatan yang signifikan dari aspek suasana kelas selama pembelajaran sesuai dengan RPP yang telah digunakan. Hal tersebut diperkuat dari hasil observasi langsung saat pelaksanaan pembelajaran serta angket respon siswa bahwa siswa senang karena merasa lebih bisa aktif untuk mendapatkan konsep yang bermakna. Dewey menggambarkan pembelajaran sebagai proses aktif individu, bukan sesuatu dilakukan untuk seseorang tetapi lebih kepada sesuatu itu dilakukan oleh seseorang dan menganggap bahwa pengalaman dan penyelidikan sangat penting dalam pembelajaran bermakna. (In'am, 2012; Martinez, 2006).

Hasil pengamatan aktivitas siswa pada uji coba replikasi di dua kelas, yaitu kelas X-1 dan kelas X-2 (Gambar 2) dapat diketahui bahwa pada aktivitas mendengarkan/memperhatikan penjelasan guru/siswa lain, mengerjakan LPPD, membaca LPPD atau materi ajar, mendiskusikan tugas, mencatat, membuat laporan hasil penelitian, mempresentasikan hasil kelompok, menyampaikan ide atau pendapat, menjawab dan menanggapi pertanyaan, merefleksi diri, dan merangkum materi pembelajaran konsisten mengalami peningkatan tiap pertemuan.

In'am (2012) dan Susantini (2009c) menyatakan bahwa strategi belajar metakognitif yang digunakan oleh guru dapat membuat siswa untuk lebih aktif dalam kegiatan pembelajaran, siswa diajarkan untuk bertanya pada diri mereka sendiri, menanamkan dasardasar berfikir ilmiah pada diri siswa sehingga dalam 
proses pembelajaran ini siswa lebih banyak aktif dalam memecahkan masalah dan dapat belajar bagaimana berpikir tentang proses-proses berpikir mereka sendiri.

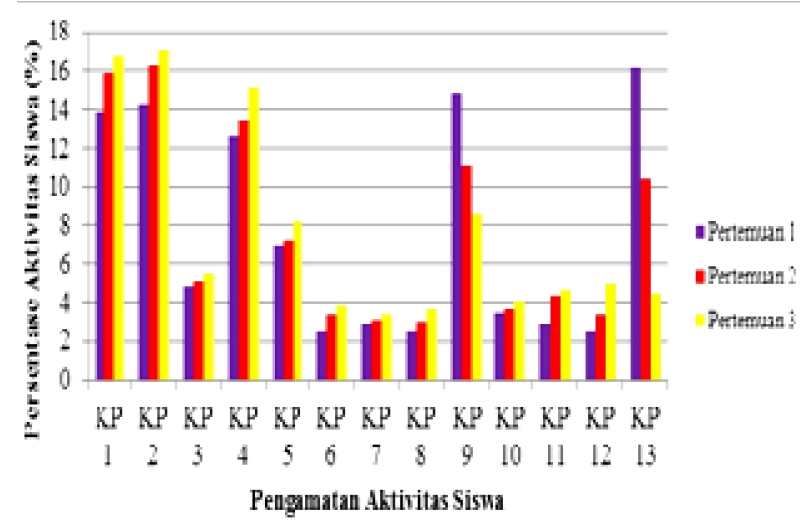

Gambar 2. Hasil pengamatan aktivitas siswa pada uji coba II di kelas X-1dan X-2 secara keseluruhan

Keterangan:

KP 1: Mendengarkan/memperhatikan penjelasan guru/siswa lain; KP 2: Mengerjakan LPPD; KP 3: Membaca LPPD/materi ajar; KP 4: Mendiskusikan tugas; KP 5: Mencatat; KP 6: Membuat laporan hasil penelitian; KP 7: Mempresentasikan hasil kelompok; KP 8: Menyampaikan ide/pendapat; KP 9: Bertanya; KP 10: Menjawab dan menanggapi pertanyaan; KP 11: Merefleksi diri; KP 12: Merangkum materi pembelajaran; KP 13: Perilaku yang tidak relevan dengan KBM.

Peningkatan aktivitas siswa tiap pertemuan menunjukkan bahwa siswa dalam kegiatan pembelajaran berada di lingkungan sosial, mereka terus menerus belajar melalui interaksi dengan orang lain di sekitar mereka. Vigotsky berpendapat bahwa perkembangan proses hidup bergantung pada interaksi dan pembelajaran sosial berperan penting untuk perkembangan kognitif (Erskine, 2009).

Aktivitas siswa menggunakan strategi metakognitif, terdapat peningkatan tiga aktivitas yang menonjol, yaitu: 1) mendengarkan/memperhatikan penjelasan guru/siswa lain; 2) mengerjakan LPPD; 3) mendiskusikan tugas. Pada aktivitas mendiskusikan tugas siswa melakukan percobaan dan pengamatan, menghubungkan hasil data percobaan dan pengamatan dengan konsep/teori yang sudah ada dari beberapa sumber, menjawab pertanyaan LPPD, dan membuat desain bagan rantai makanan.

Pada aktivitas mendiskusikan tugas siswa dikondisikan agar merasa tertantang dan penuh motivasi untuk menyelesaikan permasalahan yang ada di LPPD Biggs et. al (1997) menyatakan bahwa LPPD dapat mendatangkan pengetahuan awal siswa, mengidentifikasi miskonsepsi, memberi siswa kesempatan menggali materi yang dilakukannya sendiri. Hal ini dapat menandakan siswa bersikap jujur dalam bekerja, menyadari kesalahan diri sendiri, dan mengemukakan pendapat terhadap sesuatu apa adanya.

Aktivitas membuat laporan hasil penelitian, mempresentasikan hasil kelompok, dan menyampaikan pendapat mengalami kenaikan, tetapi tidak signifikan. Hal ini dikarenakan pengamat melihat aktivitas yang dominan pada proses pembelajaran berbasis metakognitif adalah mendiskusikan tugas untuk memperoleh jawaban dari permasalahan. Siswa diminta membuat laporan penelitian, mempresentasikan hasil kelompok, dan menyampaikan pendapat dari hasil diskusi. Aktivitas ini membutuhkan waktu sedikit daripada aktivitas lainnya. Akibatnya ketiga aktivitas ini terlihat oleh pengamat dalam jangka waktu pendek, secara sekilas, tidak terlalu dominan. Sesuai Elsina (2010) dan Flavel dalam Livingstone (1997) strategistrategi metakognitif merupakan proses-proses yang berurutan yang digunakan untuk mengontrol aktivitasaktivitas kognitif dan memastikan bahwa tujuan kognitif telah dicapai. Proses-proses ini terdiri dari aktivitas perencanaan, pemantauan, dan pengaturan serta evaluasi terhadap hasil aktivitas-aktivitas kognitif.

Aktivitas bertanya kepada guru tentang bimbingan percobaan, penyelesaian tugas belajar; dan pertama melakukan aktivitas yang tidak relevan dari pertemuan sampai ketiga mengalami penurunan yang signifikan. Peranan guru dalam pembelajaran metakognitif ini menjadi fasilitator dan membimbing siswa yang masih kesulitan dalam melakukan penyelidikan dan penyelesaian tugas. Blakey dan Spence (1990a dan 1990b) dalam pembelajaran berbasis metakognitif guru sebagai fasilitator dalam mengembangkan metakognisi siswa melalui kegiatan pembelajaran, dengan cara: membantu dan mengembangkan siswa dalam mengembangkan strategi belajar, kebiasaan baik, serta perilaku metakognitif.

Aktivitas pengerjaan LPPD kemudian mendiskusikan tugas yang ada pada LPPD mengindikasikan bahwa pembelajaran metakognitif dapat merangsang siswa untuk mengoptimalisasikan pikiran siswa untuk meregulasi diri sendiri dengan melakukan perencanaan, pengarahan, dan evaluasi terhadap tugas yang sedang dikerjakan. Ditinjau dengan hasil tes pengetahuan, siswa yang kurang aktif selama proses pembelajaran mendapatkan nilai baik (B-, B, dan $\mathrm{B}+$ ). Hasil ini mengindikasikan bahwa aktivitas dalam pembelajaran metakognitif relevan dengan hasil belajar siswa.

Ujicoba hasil pengembangan perangkat secara konsisten dapat meningkatkan ketuntasan aspek pengetahuan siswa, dengan $n$-gain rata-rata dari kelas X-1 dan X-2 adalah 0,87 dan 0,88 dengan kategori tinggi (Hake, 1999) dan siswa dapat mencapai ketuntasan indikator pembelajaran aspek pengetahuan yang telah ditetapkan dengan rata-rata ketuntasan 
tujuan pembelajaran pada kelas X-1 dan X-2 sebesar 96,94\% dan 95,56\% (Gronlund \& Linn, 1995).

Ketuntasan hasil belajar siswa menunjukkan bahwa keseluruhan siswa sudah menguasai konsep yang telah diajarkan, baik sub bab materi pengertian, komponen, dan tipe-tipe ekosistem; rantai makanan dan jaring-jaring makanan; serta daur biogeokimia dan suksesi. Tes hasil belajar aspek pengetahuan ini terdiri dari 13 indikator pembelajaran, yang dijabarkan dalam 10 soal pilihan ganda dan 15 soal uraian dengan menggunakan taksonomi Bloom baru (direvisi oleh Anderson \& Krathwoll) dari $\mathrm{C}_{1}$ (mengingat) sampai $\mathrm{C}_{6}$ (mencipta).

Konsep-konsep yang dipertanyakan pada tes hasil belajar aspek pengetahuan siswa merupakan tujuan pembelajaran yang sudah pernah dibahas pada saat proses pembelajaran berlangsung. Pertanyaan yang diujikan sudah pernah diberikan pada LPPD. Lembar Penilaian Pemahaman Diri (LPPD) berisi pertanyaan mengenai konsep-konsep penting yang dipelajari pada masing- masing sub bab materi yang akan disampaikan pada pertemuan tersebut. Peningkatan $n$ gain menunjukkan ujicoba terbatas dari pengembangan perangkat pembelajaran Biologi berbasis metakognitif efektif dalam meningkatkan penguasaan aspek pengetahuan pada materi ekosistem. Pernyataan ini diperkuat dengan hasil penelitian Yasir (2013), Yuliani (2013), Indana (2009), dan Nur (2005) yang menyatakan bahwa pembelajaran dengan menggunakan strategi metakognitif dapat meningkatkan hasil belajar kognitif siswa. Sikap kejujuran siswa ditandai dengan indikator:

Sikap kejujuran siswa ditandai dengan indikator: 1) tidak menyontek dalam mengerjakan ujian, 2) tidak plagiat (mengambil/menyalin karya orang lain tanpa menyebutkan sumber dalam mengerjakan setiap tugas), 3) mengemukakan pendapat terhadap sesuatu apa adanya, 4) melaporkan barang yang ditemukan, 5) melaporkan data atau informasi apa adanya, 6) mengakui kesalahan atau kekurangan yang dimiliki. Kejujuran siswa secara ratarata dari 72 siswa yang teramati selama melaksanakan pembelajaran strategi metakognitif pada kelas X-1 dan X-2 adalah $98,22 \%$ dan $97,67 \%$ selama tiga pertemuan dengan kategori sangat baik (Kemendikbud,2013).

Peningkatan sikap kejujuran siswa pada setiap pertemuan dapat disimpulkan bahwa pembelajaran menggunakan strategi metakognitif dapat melatihkan kejujuran siswa. Hal tersebut mengindikasikan bahwa dengan menggunakan strategi metakognitif siswa dapat lebih jujur dalam perkataan, tindakan, dan pekerjaan, meskipun ada beberapa siswa yang tidak jujur dikarenakan selain wataknya juga kebiasaan diri siswa yang memang belum bisa berbuat jujur dalam perkataan, tindakan, dan pekerjaan. Sikap $\begin{array}{llllll}\text { ketidakjujuran } 2 \text { siswa kelas } & \mathrm{X}-1 & \text { dan } & 1 & \text { siswa }\end{array}$ kelas X-2 menunjukkan kesinkronan antara hasil pengamatan sikap siswa (Tabel 1) dan rekapitulasi angket kejujuran siswa (Gambar 3).

Tabel 1. Persentase sikap kejujuran siswa tiap pertemuan dari hasil pengamatan.

\begin{tabular}{c|c|c|c|}
\hline \multirow{2}{*}{$\begin{array}{c}\text { Lisial } \\
\text { Siswa }\end{array}$} & \multicolumn{3}{|c|}{$\begin{array}{c}\text { Persentase Aspek Sikap } \\
\text { Kejujuman Siswa (96) }\end{array}$} \\
\cline { 2 - 4 } & TM 1 & TM 2 & TM 3 \\
\hline$x-1$ & 75 & 81,25 & 91,67 \\
\hline$x-2$ & 75 & 84,72 & 98,61 \\
\hline
\end{tabular}

Keteranagan;

TM 1: Tatap muka 1; TM 2: Tatap muka 2; TM 3: Tatap muka 3.

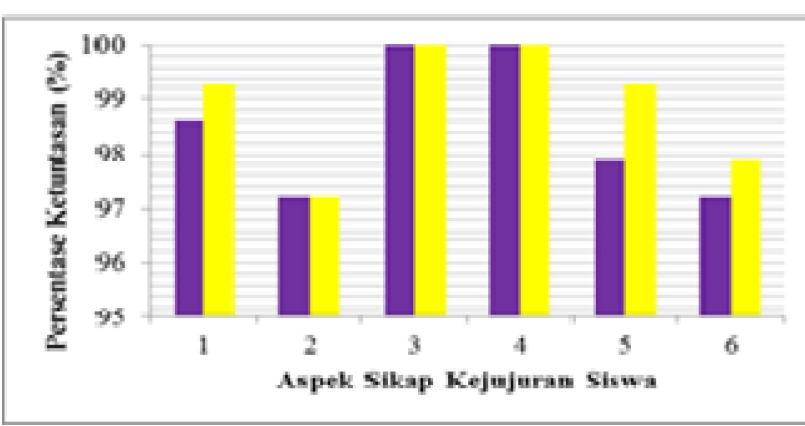

Gambar 3. Persentase ketuntasan kejujuran siswa antara kelas X-1 dan X-2 dilihat dari indikator karakter pada uji coba II dari hasil angket

Berdasarkan pengamatan sikap kejujuran siswa selama pembelajaran (Tabel 1) tergolong berkembang, walaupun tidak semua siswa berkembang karena hanya terbatas 3 kali pertemuan. Strategi metakognitif merupakan strategi yang dapat membantu siswa menyadari kesalahan konsep dan memperbaikinya dengan jalan mengajukan pertanyaan pada diri sendiri (Peirce, 2003 dan Baker, 2003). Penyadaran konsep yang salah sehingga mau mengakui kesalahan merupakan salah satu dari indikator kejujuran.

Kejujuran dapat mengindikasikan bagaimana siswa tersebut mengatur proses kognitifnya melalui pemberdayaan keterampilan metakognitif (Case, 2010). Pernyataan ini diperkuat dengan hasil penelitian yang dilakukan Susantini $(2004,2005)$ bahwa manfaat dari strategi metakognitif sejalan dengan Kurikulum 2013 pada Kompetensi Inti/Kompetensi Dasar pada aspek sikap sosial yaitu dapat menumbuhkan sikap jujur dan berani mengakui kesalahan. Data hasil penelitian dan temuan beberapa sumber maka dapat dinyatakan perangkat pembelajaran Biologi berbasis metakognitif dapat melatihkan dan mengembangkan sikap jujur.

Analisis respon siswa terhadap perangkat pembelajaran (yang meliputi: buku ajar siswa dan LPPD), serta pelaksanaan pembelajaran dengan strategi metakognitif (Gambar 4) didapatkan hasil bahwa pada kelas X-1 sebanyak $98,52 \%$ dan kelas X-2 $99,23 \%$ siswa merespon sangat baik. Hasil tersebut 
secara keseluruhan dari 2 kelas menunjukkan $98,87 \%$ siswa merespon positif.

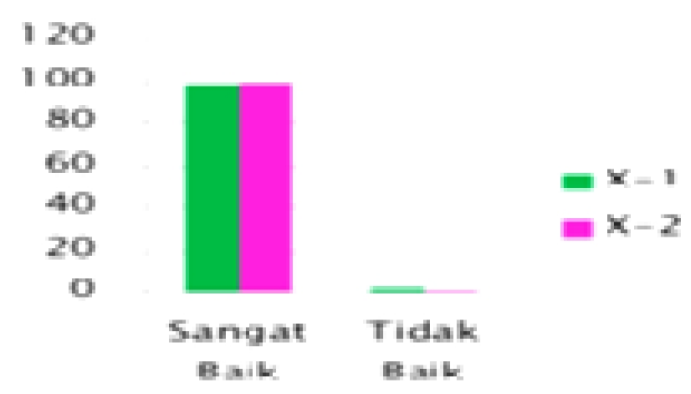

Gambar 4. Hasil analisis data respon siswa pada uji coba II di kelas X-1 dan X-2

Persentase paling tinggi terdapat pada respon yaitu: 1) sifatnya baru; 2) pembelajaran biologi seperti ini membuat saya semangat, senang, tertarik, dan termotivasi untuk menyimak materi yang dipelajari; 3) pembelajaran seperti ini memudahkan saya untuk memahami materi; 4) saya melihat kembali konsep awal saya pada LPPD individu sebelum menentukan "apakah konsep awal saya berbeda dengan konsep baru yang saya peroleh"; 5) saya dapat mengidentifikasi apa yang telah dipelajari, apa yang belum dikuasai (learning needs) serta rencana pengembangan diri selanjutnya berdasarkan learning needs yang telah diidentifikasi.

Analisis data respon siswa juga menyebutkan bahwa ada beberapa siswa yang belum mampu mempertahankan perhatian dalam jangka waktu panjang. Kemungkinan hal tersebut dipengaruhi oleh faktor eksternal seperti gangguan lingkungan di dalam dan di luar kelas. Solusi yang dimunculkan adalah meminimalkan gangguan dengan cara menciptakan lingkungan pembelajaran yang kondusif. Cara menciptakan lingkungan kondusif, yaitu 1) mendesain lingkungan fisik (sarana dan prasarana fisik belajar, dalam hal ini ruang kelas belajar) dengan baik, dan 2) pengelolaan kelas yang positif untuk pembelajaran. Menurut Everston et al. (dalam Santrock, 2008), terdapat empat prinsip yang dapat dipakai dalam menata kelas, yaitu: a) kurangi kepadatan di tempat lalu lalang (pastikan mudah diakses siswa), b) pastikan bahwa guru dapat dengan mudah melihat semua anak. (memonitor belajar siswa), c) materi pengajaran dan perlengkapan anak harus mudah diakses, d) pastikan siswa dapat dengan mudah melihat semua presentasi kelas. Analisis respon siswa terhadap pengembangan perangkat dan pelaksanaan pembelajaran selama uji coba adalah positif. Hasil ini sesuai dengan hasil penelitian dari Yasir (2013); In'am, (2012); Susantini (2009); Indana (2009); Paris dan King dalam Slavin (2009); dan Corebima $d k k$, (2006) yang menyatakan bahwa dengan menggunakan strategi metakognitif untuk melatihkan kejujuran mendapatkan respon positif dari siswa.

\section{KESIMPULAN}

Berdasarkan hasil analisis, diskusi, dan pembahasan, maka dapat dibuat simpulan bahwa perangkat pembelajaran Biologi berbasis metakognitif yang dikembangkan sudah valid, praktis, dan efektif untuk melatihkan kejujuran siswa.

\section{REFERENSI}

Baker, L. (2003). Metacognition. On line. (http://academic.pgcc.edu/ wpeirce/MCCCTR/ me tacognition.htm, diakses tanggal 5 Oktober 2014).

Barakatu, A.R. (2007). Membangun Motivasi Berprestasi: Pengembangan Self Efficacy dan Penerapannya dalam Dunia Pendidikan. Lentera Pendidikan, X 1: 34-51.

Biggs, A., Daniel, L., \& Ortleb, E.. (1997). Life Science. Teacher Wraparound Edition. New York: Glencoe McGraw Hill.

Blakey, E \& S. Spence. (1990a). Metacognitive Behaviors, On line.(http://www.ncrel.org./sdrs/areas/issues/stud ents/l earning/Ir2behav.htm, diakses tanggal 20 Maret 2015).

Blakey, E \& S. Spence, (1990b). Metacognitive Skill. On line. (http://education.calumet.perdue.edu/vockell/Ed Ps yBook/Edpsy7/edpsy7_meta.htm, diakses tanggal 20 Maret 2015.

Borich, G.D. (1994). Observation Skill for Effective Teaching, Second Edition. USA: Macmillan Publishing Company.

Case, A. (2010). Albinisme. Jakarta. http://www.flickr.com/photos/caseorganic/3760 51534/albinisme.jpg diakses pada tanggal 5 Oktober 2014).

Corebima, A.D. (2006). Pengalaman Berupaya Menjadi Guru Profesional. Pidato Pengukuhan guru Besar Bidang Genetika. Malang: FMIPA Universitas Negeri Malang.

Emosda. (2013). Penanaman Nilai-Nilai Kejujuran Dalam Menyiapkan Karakter Bangsa. Jambi. On Line (http://psikologi-univ jambi.blogspot.com/2013/09/cara-mengajarkananak-bersikap-jujur.html, diakses pada tanggal 9 September 2014.

Erskine, D.L. (2009). Effect of Prompted Reflection and Metacognitive Sskill Instruction on University Freshmen's use of Metacognition. Brigham Young University.

Gronlund, N. E. \& Linn, R. L. (1995). Measurement and assesment in teaching (7th ed). New Jersey: Merril Englewood Cliffs. 
Hake, R. (1999). Analyzing Change Gain Scores. USA: Indiana University.

Ho, I dan Kelly, Y.L. (2010). Metacognitive strategies that enhance critical thinking. Hongkong. Journal American Educational Research Association Annual Meeting, 5: 251267.

In'am, A. (2012). A Metacognitive Approach to Solving Algebra Problems. Malang. International Journal of Independent Research and Studies -IJIRS ISSN: 2226-4817; EISSN: 2304-6953 Vol. 1, No.4 (October, 2012) 1 62-173 Indexing and Abstracting: Ulrich's - Global Serials Directory.

Indana, S. (2009). Efektivitas Perangkat Pembelajaran Virus Dengan Strategi Metakognitif Terhadap Perolehan Kognitif Siswa SMA Kelas X. Prosiding Seminar Nasional Penelitian Pendidikan dan Penerapan MIPA. Yogyakarta Fakultas MIPA Universitas Negeri Yogyakarta.

Kemendikbud. (2013). Pendekatan ilmiah dalam Pembelajaran. Jakarta Kementerian Pendidikan dan Kebudayaan.

Martinez, M. (2006). What is metacognition? Teacher intutyvely recognize the importance of metacognition but no be aware of itsmany dimensions. On line., diakses pada tanggal 26 Maret 2015.

Nindiasari, H. (2011). Pengembangan Bahan Ajar dan Instrumen untuk Meningkatkan Berpikir Reflektif Matematis Berbasis Pendekatan Metakognitif pada Siswa Sekolah Menengah Atas (SMA). Yogyakarta. Jurnal Pendidikan Matematika FMIPA UNY, P-23.

Nur, M. (2005). Strategi-Strategi Belajar. Surabaya: UNESA-University Press.

Peirce, W. (2003). Metacognition: Study Strategies, Monitoring, And Motivation. On line. (http://website-tools.net/googlekeyword/site/education.calumet.purdue.edu, diakses tanggal 29 September 2014).
Ratumanan, G. T. dan Laurens. (2011). Evaluasi hasil belajar pada tingkat satuan pendidikan. Surabaya: Unesa Unversity Press.

Rustaman. N., R. Amini, Arifin, Mulyati, dan A. Munandar. (2005). Strategi Belajar Mengajar Biologi. Malang: Universitas Negeri Malang.

Slavin, R. (2009). Educational Psychology: Theory and Practice. Boston: Allyn Bacon.

Susantini, E. (2004). Strategi Metakognitif dalam Pembelajaran Kooperatif untuk Meningkatkan Kualitas Proses Pembelajaran Genetika di SMA. Artikel disertasi doktor Pendidikan Biologi Program Pasca Sarjana Universitas Negeri Malang.

Susantini, E. (2009a). Pengaruh Kemampuan Siswa terhadap Perolehan Kognitif dan Metakognitif pada Pembelajaran Biologi. Berkala Penelitian Hayati Edisi Khusus No. 3E: 31-36.

Susantini, E. (2009b). Pengembangan Perangkat Pembelajaran Biologi dengan Strategi Metakognitif untuk Memberdayakan Kecakapan Berpikir Siswa SMA. Laporan Penelitian Dikti Perpustakaan Universitas Indonesia.

Susantini, E. (2009c). The Development of Biology Material Resources by Metacognitive Strategy. Jurnal Ilmu Pendidikan. Juni 2009, Jilid 16, (2): 88-93.

Yasir, M. (2013). Pengembangan Lembar Kerja Siswa (LKS) Untuk Meningkatkan Hasil Belajar Siswa. Skripsi. Tidak dipublikasikan. Surabaya: Universitas Negeri Surabaya.

Yuliani, U. (2013). Kemandirian dan Keterampilan Berpikir Kritis Siswa Melalui Pembelajaran Biologi Bercirikan Metakognitif. Tesis. Tidak dipublikasikan. Surabaya: Universitas Negeri Surabaya. 